\title{
Examining the Resiliency of Preschool Children in the COVID-19 Pandemic Period Based on Age and Gender
}

\author{
Hülya Gülay-Ogelman \\ Sinop University \\ Hande Güngör ${ }^{2}$
Pamukkale University \\ ilkay Göktaş3 \\ Ondokuz Mayıs University
}

\begin{abstract}
Since the beginning of the coronavirus pandemic, various measures have been taken in Turkey to protect community health. All schools in Turkey have been closed since 16 March 2020. The normalization process started along with the decrease in the number of cases in summer, and children's lockdown was abolished on 10 June 2020. Rearising of cases as from August delayed the planned opening of the 2020-2021 academic year fall term. Thus, the Ministry of National Education, which is among the institutions taking new measures related to the process, created a stage-by-stage transition plan, in which faceto-face education and distance education are carried out in cooperation, for the opening of schools. Main goal of the study was to examine the egoresiliency levels of the children between the ages of five and six years according to age and gender variables during the COVID-19 period. The study group consisted of 223 children from the age group of five and six years. As a result of the study, it was found that girls had higher resiliency levels than their boys peers. Another finding was that there was no significant difference in the resiliency levels of the children between the ages of five and six years.
\end{abstract}

Submitted

12 July 2021

Revised

26 December 2021

Accepted

28 December 2021

Keywords:

COVID-19,

Ego-resiliency,

Preschool children.

\section{Suggested Citation:}

Gülay-Ogelman, H., Güngör, H. \& Göktaş, İ. (2021). Examining the resiliency of preschool children in the Covid-19 pandemic period based on age and gender. International Journal of Academic Research in Education, 7(1), 29-37. DOI: 10.17985/ijare.970400

\footnotetext{
${ }^{1}$ Sinop University, ogelman@ sinop.edu.tr

${ }^{2}$ Pamukkale University Department of Nursing and Care Services/Child Development, hgungor@pau.edu.tr

${ }^{3}$ Ondokuz Mayıs University, Department of Nursing and Care Services/Child Development, ilkay.goktas@omu.edu.tr
} 


\section{INTRODUCTION}

One could say that entire world is currently under the influence of the pandemic. According to the data on 31 December 2021 global cases have surpassed 285 million (BBC NEWS, 2021). The coronavirus causing the pandemic causes pneumonia-like symptoms in people who contact the virus, such as high fever, dry cough and fatigue. The disease caused by the virus has been named as COVID-19 (Budak and Korkmaz, 2020). COVID-19 has had many negative impacts on people not only physiologically, but also psychologically. The pandemic may lead to anxiety, stress and behavioral disorders for people. Besides the fear of getting sick and losing the loved ones to the disease; the lockdowns in the pandemic period have altered people's routine life fluency and restricted their freedom, which has affected their psychological health negatively (Aslan, 2020).

Since the beginning of the coronavirus (COVID-19) pandemic, various measures have been taken in Turkey to protect community health. All schools in Turkey have been closed since 16 March 2020. A circular letter which was sent to all provincial governorships by command of the President on 3 April 2020, imposed a temporary lockdown on those under the age of 20 years. People who were between the ages of 18 and 20 years, civil servants, contracted staff or workers working in state institutions and organizations, those who had a regular job in the private sector and were able to document their social security register and seasonal agricultural workers having an important function in the continuity of agricultural production, were exempt from the lockdown.

The normalization process started along with the decrease in the number of cases in summer, and children's lockdown was abolished on 10 June 2020. Rearising of cases as from August delayed the planned opening of the 2020-2021 academic year fall term. Thus, the Ministry of National Education, which is among the institutions taking new measures related to the process, created a stage-by-stage transition plan, in which face-to-face education and distance education are carried out in cooperation, for the opening of schools. According to this plan, preschool educational institutions and first graders started school and conducted face-to-face part-time education two days a week. In line with the stage-by-stage plan, the second stage started on 12 October 2020. In this stage, the classes were grouped according to social distancing based on the number of students and it was determined that the course time was 30 minutes, and the recess time was 10 minutes. Since that date, it has been decided to conduct face-toface education in preschool educational institutions as six activity hours five days a week. In this process, some parents have refused to send their children to school for face-to-face education due to anxiety and as a precaution. Therefore, the provincial directorates of national education have received written consent from these parents and declared that their children will not be considered absent from school. These children continue their lessons via distance education in primary school and upper levels. There has been no online preschool education program applied synchronously for preschool children who were unable to go to school across Turkey in March, April and May, 2020. In official preschool educational institutions, the Ministry of National Education has given initiative to teachers concerning online education for young children. Private preschool educational institutions have conducted online education applications showing different properties (every day or in different hours on certain days).

Together with the increase in the number of cases, the stage-by-stage face-to-face education process was evaluated again and distance education restarted in all official, private, formal and informal educational activities after an explanation made by the Ministry of National Education on 17 November 2020 until 31 December 2020. Suspension of face-to-face education until 31 December 2020 due to COVID-19 has aroused reactions especially among working mothers. Due to these reactions, the General Directorate for Basic Education declared the continuation of face-to-face education five days a week in preschool 
educational institutions, which were evaluated again by the Ministry of National Education, via a letter dated 20 November 2020 and numbered 16988740 (The Ministry of National Education, 2020). As a result of the feedback received from the relevant governorships concerning face-to-face preschool education conducted in this process, the resolution for official kindergartens and nursery classes to start distance education until 4 January 2021 depending on the course of the COVID-19 pandemic in residential areas as from 23 November 2020, was relinquished to the opinions of provincial/district sanitation committees. In the context of this resolution, sanitation committees of twelve provinces in Turkey (Sivas, Kayseri, Yozgat, Samsun, Gaziantep, Erzurum, Edirne, Balikesir, Ankara, Zonguldak, Kirklareli and Tokat) enacted that educational activities in official kindergartens, nursery classes and practice classes across the province would be maintained via distance education between 30 November 2020 and 4 January 2021.

In order to take the pandemic under control, new measures were taken across Turkey on 30 November 2020. After an explanation made by the Presidency on 30 November 2020, face-to-face education of all official and private preschool educational institutions and nursing homes was resuspended as from 1 December 2020 until 4 January 2021 and activities in official kindergartens, nursery classes and practice classes in affiliation with the Ministry of National Education were to be maintained via distance education.

With the announcement of Ministry of National Education (MEB) (2021a), it was stated that the second semester of the 2020-2021 academic year will start on Monday, February 15th. In the announcement, it was stated that village schools and kindergartens across Turkey would be opened face-to-face on Monday, February 15, 2021, and as of March 1, 2021, face-to-face education would be offered in diluted form in all public and private primary schools and in kindergartens and special education classes within these primary schools. With the statement made by the MEB (2021b) on March 1, 2021, it was stated that as of Tuesday, March 2, full-time face-to-face education would begin in all pre-school education institutions in all low, medium and high-risk provinces by taking COVID 19 precautions. With this announcement, on March 2, 2021, preschool education institutions across Turkey started full-time faceto-face education. In this process, while paying attention to mask, distance and hygiene among the COVID-19 measures taken, common classroom materials in preschool education were not used in classes to reduce contact. No changes were made in pre-school education institutions in the 2020-2021 spring term. The fall semester of the 2021-2022 academic year started with integration training for pre-school and first grade students between 1-3 September 2021. On September 6, 2021, full-time face-to-face education began at all levels. In this process, masks and hygiene rules continue to be valid in pre-school education institutions, and educational materials have started to be used in the classroom again.

This process has brought the need for studies on the resiliency of children. Resiliency expresses the adaptation ability in the face of negative and traumatic conditions (Masten and Coatsworth, 1998; Mihaela, 2015). In challenging processes, the most important factors for preschool children to develop social and emotional well-being are mother-father-child relationship, teacher-child communication and skills of expressing emotions and coping with emotional and social problems (Mihaela, 2015). The person's resiliency depends on his/her adaptation to the present situation as a result of the interaction between the risk factors he/she has in the face of negative conditions and protective factors (Önder and Gülay, 2008).

In our world where challenging conditions gradually increase and a stress-free life seems to be impossible, it is becoming more and more important to increase the resiliency of children. Resiliency includes the person's adaptation to changes in his/her life in the face of negative events during the interaction process of protective factors and risk factors. Risk factors can be expressed as individual, familial and environmental disasters and negative experiences that may be faced by the person in life. These situations may be encountered as chronic illnesses, parents' divorce or a pandemic. Protective 
factors can be examined as internal factors (such as self-confidence, intelligence, optimistic viewpoint) and external factors (such as close relationship with the environment, parental relationship, consistent care, supportive relationships, having good socio-economic conditions). It is thought that protective factors reduce the negative impacts of risk factors in the face of negative experiences (Afifi and MacMillan, 2011; Gizir, 2007; Karaırmak, 2006).

Through resiliency, children are able to overcome the traumas with less damage. Parents play a key role in increasing the resiliency skills of children. Young children are not able to cope with challenging conditions alone. In such situations the support that children receive from their families and actually the resiliency status of families affect the resiliency of children (Grotberg,1995; Masten and Gewirtz, 2006). When children experience challenging conditions in situations where they receive adequate support, this may contribute to the increase of their resiliency (Beyond Blue Ltd., 2017).

Exceptional circumstances, which have been faced in the pandemic period, have affected children substantially. Many conditions during this period such as being physically less active, being isolated from social life, and fearing the disease create a risk factor for children and consequently affect their psychology (Çalışkan, 2020; Turan and Hacımustafaoğlu, 2020).

In this period where risk factors are unavoidable, examining the resiliency levels of children is crucial for determining and enhancing the protective factors and giving support to children.

\section{Purpose of the study}

The study was conducted to determine the resiliency levels of preschool children during the lockdown imposed on young children in the COVID-19 pandemic period. Within the context of this purpose, answers were sought to the following questions:

1. What are the resiliency levels of preschool children during the COVID-19 period?

2. Do the resiliency levels of preschool children vary based on gender during the COVID-19 period?

3. Do the resiliency levels of preschool children vary based on age during the COVID-19 period?

\section{METHOD}

The study is a descriptive study conducted in the survey model to examine the resiliency levels of children between the ages of five and six years in terms of some variables.

\section{Participants}

The study group consisted of 223 children from the age group of five and six years living in different provinces in Turkey.

Table 1. Demographic Data Related to the Study Group

\begin{tabular}{|c|c|c|c|}
\hline \multicolumn{2}{|c|}{ Personal Information } & \multirow{2}{*}{$\frac{\mathrm{n}}{104}$} & \multirow{2}{*}{$\begin{array}{c}\% \\
46.6\end{array}$} \\
\hline \multirow{3}{*}{ Gender } & Girl & & \\
\hline & Boy & 119 & 53.4 \\
\hline & Total & 223 & 100 \\
\hline \multirow{3}{*}{ Age } & 5 year & 118 & 52.9 \\
\hline & 6 year & 105 & 47.1 \\
\hline & Total & 223 & 100 \\
\hline
\end{tabular}


When examining Table 1, it was seen that 104 of the participants were girl (46.6\%) and 119 were boys (53.4\%). Also in Table 1, 118 (52.9\%) of the children in the study were five years old and 105 (47.1\%) were six years old.

\section{Measurements}

Personal information form

In the study, the Personal Information Form, prepared by the researchers, was used to determine the gender and age information of children.

\section{Children's Ego-Resiliency Scale (Mother-Father Form)}

The Children's Ego-Resiliency Scale (Mother-Father Form) was used to determine the data concerning the resiliency of children. Eisenberg and colleagues to develop the Children's Ego-Resiliency Scale in 1996 by adapting Block's Q-Sort method (Önder \& Gülay Ogelman, 2011). The scale has mother-father and teacher forms. Adapted into Turkish by Önder \& Gülay Ogelman (2011), the Children's Ego-Resiliency Scale is a nine-point likert scale comprising twelve items and one subscale. It is accepted that high scores signify the increased ego-resiliency levels of children and lower scores signify their decreased levels of ego-resiliency. The Cronbach's a coefficient of the Children's Ego-Resiliency Scale was found to be 0.86 . In the study, the Cronbach's a coefficient of the Children's Ego-Resiliency Scale was found to be 0.64.

\section{Procedure}

In the data collection process, the Google Form programme was used. The Personal Information Form which was prepared via the Google Form programme and the Children's Ego-Resiliency Scale were sent to children's parents in the electronic media to be completed.

\section{Data Analysis}

The data of the study were analysed in the SPSS 22.0 statistical package programme. Since the Normality Tests for variables were required to determine which tests to use for the study data (Özdamar, 2004), the One Sample Kolmogorov-Smirnov Test was primarily used to analyse the data acquired in the study. At the end of the Kolmogorov-Smirnov Test analysis, it was found that the scores (K-S(Z)=.052) obtained by children from the Ego-Resiliency Scale, which was the dependent variable in the study, were normally distributed ( $p>0.05)$. Whether or not the resiliency levels of the children varied based on gender and age in the Covid-19 process was analysed via the t-test.

\section{FINDING}

Table 2. Mean and Standard Deviation Values of the Ego-Resiliency Scale Scores of the Children

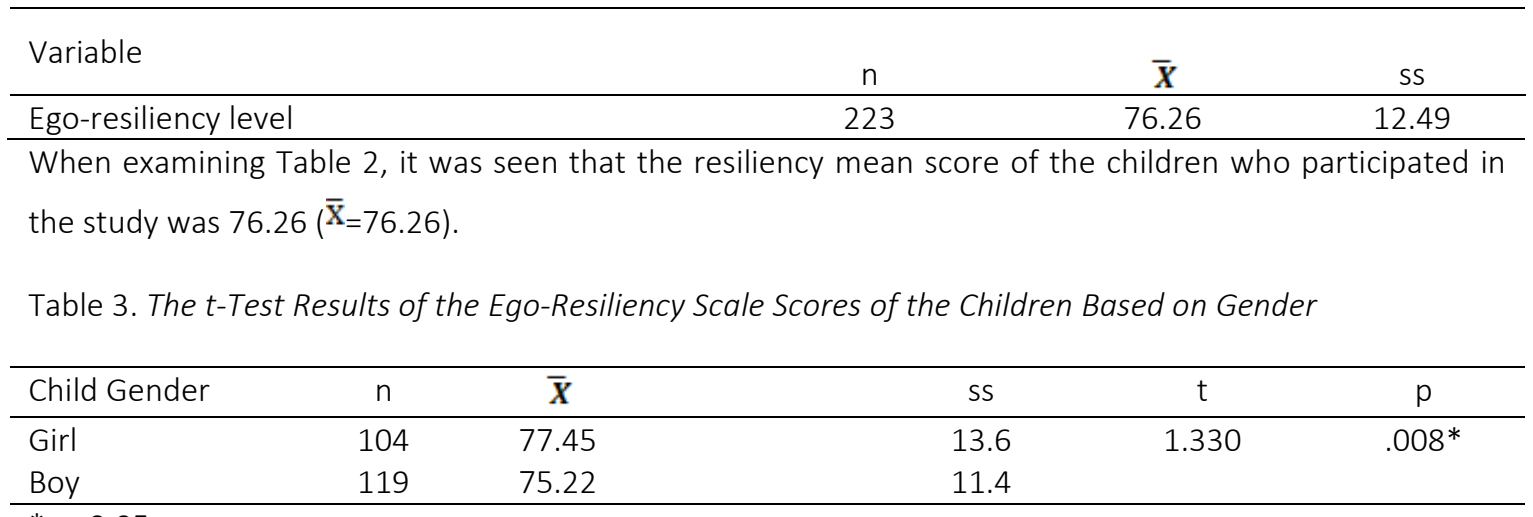

$* p<0.05$ 


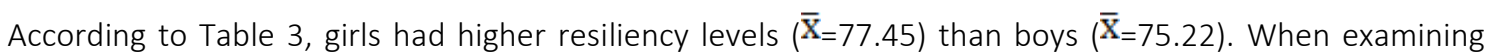
Table 3, it was seen that this difference between the mean scores was statistically significant $(\mathrm{t}=1.330$, $p<0.05)$.

Table 4. The t-Test Results of the Ego-Resiliency Scale Scores of the Children Based on Age

\begin{tabular}{lccccc}
\hline Child's Age & $\mathrm{n}$ & $\overline{\boldsymbol{X}}$ & $\boldsymbol{s s}$ & $\mathrm{t}$ & $\mathrm{p}$ \\
\hline Five Years & 118 & 75.40 & 11.9 & -1.088 & .235 \\
Six Years & 105 & 77.22 & 13.0 & & \\
\hline
\end{tabular}

According to Table 4, six-year-old children had higher resiliency levels ( $\bar{X}_{=77.22)}$ compared to five-yearold children $\left(\bar{x}_{=75.40)}\right.$. When examining Table 4 , it was determined that the difference obtained was not significant at the level of 0.05 ( $t=-1.088, p>0.05)$.

\section{DISCUSSION and CONCLUSIONS}

Main goal of the study was to examine the ego-resiliency levels of the children between the ages of five and six years according to age and gender variables during the COVID-19 period. As a result of the study, it was found that girls had higher resiliency levels than their boys peers. Another finding was that there was no significant difference in the resiliency levels of the children between the ages of five and six years. In the literature, there are studies supporting and not supporting this finding. For example, 288 children between the ages of 60 and 72 months and their mothers participated in a study conducted in Turkey (Bayındır, Balaban Dağal \& Önder, 2018). According to the findings of the study it was determined that emotion regulation skills in preschool children varied according to the ego-resiliency level. It was found that age and gender variables had no effect on the ego-resiliency and emotion regulation skills of children. In addition, when considering the combined effect of gender, age and emotion regulation skill on ego-resiliency, it was determined that these three variables were not effective on the ego-resiliency level. Also in some studies it has been stated that as the age of children increases, their ego-resiliency may increase (Block \& Block, 2006; Miljević-Riđički, Plantak, \& Bouillet, 2017). In a study conducted by Adagideli and Sahan Aktan (2018) with children between the ages of 48 and 72 months, they found that age was effective on ego-resiliency, but gender was not. Although a finding was obtained on behalf of girls in terms of gender in this study, some studies suggest that there is no difference between genders (Adagideli \& Şahan Aktan, 2018; Bayındır, Balaban Dağal \& Önder, 2018), while some studies state that there may be a gender difference (Block \& Block, 2006; Sun \& Stewart, 2007). In the present study girls had higher ego-resiliency scores than boys, which can be explained with the attitudes of parents towards girls. It can be asserted that Turkish families may have a viewpoint expecting girls to obey the rules more and be stronger, skilful and talented and boys to be more confident and free. In a study conducted by Yağan Guder (2014) to examine the gender perceptions of preschool children, it was found that mothers had greater expectations from girls and their primary expectation from girls was assistance in housework. It was concluded that their expectations from girls and boys were in agreement with the traditional role sharing. In a study conducted by Binbaşığlu (1998), it was determined that Turkish families were more attentive about the needs of boys than the needs of girls and appreciated the misbehaviours of boys more than the misbehaviours of girls.

In addition, some studies suggest that there may be a gender difference in skills related to social and emotional development areas in the preschool period in Turkey. For example, in their study Gültekin Akduman, Gunindi and Türkoğlu (2015) found that girls had higher social skill levels than their boys peers. In their study, Corapçı, Aksan, Arslan-Yalçın and Yağmurlu (2010) determined that girls were considered more socially competent than boys and they displayed angry and furious behaviours less. In a study 
conducted by Gülay Ogelman and Çiftçi Topaloğlu (2014) with 227 children between the ages of four and five years and their parents, they found that girls had higher social competence scores than boys. When examining the aggression and anxiety scores of children between the ages of four and five according to gender, it was observed that there was no significant difference between them. As is seen, the literature may have findings supporting and not supporting the gender difference related to emotional and social variables.

The fact that the ego-resiliency level did not vary according to age in the present study was thought to be likely associated with the effect of different variables. Besides variables like age and gender; factors like temperament, serotonin-specific genetic variability, lower socio-economic level, parent's illness, unemployment, divorce, loss of a parent and negative parental behaviours may harm and/or reduce egoresiliency (Eisenberg et al., 2004; Reed Victor \& Stronge, 2002; Taylor et al., 2014; Um, 2018). In general terms it is indicated that ego-resiliency in the first years of life is associated with popularity and social competence in peer relationships in the childhood and adolescence (Cumberland-Li, Eisenberg and Reiser, 2004; Swanson, Valiente, Lemery-Chalfant and O'Brien, 2011). In line with the findings obtained from the studies, it is possible to state that it is important to support ego-resiliency as from early ages for a healthy development.

The psychological resilience of the children within the scope of the study was limited to the scores obtained with the "Children's Ego Resilience Scale". Children's Ego Resilience Scale is limited to one subdimension. The results of the study are limited to the parental views of 223 children. The independent variables of the study were considered to the age and the gender. Considering the limitations of the study and the social effects of the coronavirus, it would be appropriate to make some suggestions for future studies. Subsequent studies which reach larger study groups and represent different socio-economic levels, will be important for the richness of the findings. Different age groups and larger sample groups may also be considered in future studies. The opinions of teachers and children can be consulted in determining the psychological resilience of children. Families should be informed about psychological resilience in the preschool period and should be encouraged to guide their children. In addition, studies should be conducted to address the effects of the COVID-19 pandemic process on the behavior and competences of young children. As this study was conducted during the curfew period for young children, it may be interesting to compare the results of the repeated study during the period when children continue face-to-face education in continuing the pandemic period. In addition, it is important that preschool teachers are informed about the psychological resilience of children to enhance their decisions regarding the ongoing education process and interactions with the children. 


\section{References}

Afifi, T. O., \& MacMillan, H. L. (2011). Resilience following child maltreatment: A review of protective factors. The Canadian Journal of Psychiatry, 56(5), 266-272.

Adagideli, F., \& Şahan Aktan, B. (2018). Components of effortful control and their relations to children's ego-resiliency. International Primary Education Research Journal, 2(1), 1-8.

Aslan, R. (2020). How does COVID 19 effect physıology and psychology? Detail Journal, 8(88), $47-53$ (in Turkish).

Bayındır, D, Balaban Dağal, A, \& Önder, A. (2018). The ınvestigation of emotion regulation skills according to ego resiliency levels of 60-72 months old Turkish preschoolers. Adiyaman University Journal of Social Sciences, 29, 377-400. (in Turkish).

BBC NEWS, (2021). Coronavirus map. 03 January 2021 retrieved from https://www.bbc.com/turkce/haberler-dunya-51719684 (in Turkish)

Beyond Blue Ltd. (2017). Building resilience in children aged 0-12: A practice guide. 01 December 2020 retrieved from https://www.beyondblue.org.au/who-does-it-affect/children/building-resilience-inchildren-aged-0-12.

Binbaşıoğlu, C. (1998). A study on child education in Turkey according to traditional culture. Ankara: Republic of Turkey Ministry of Culture Publications (in Turkish).

Block, J., \& Block, J. H. (2006). Venturing a 30-year longitudinal study. American Psychologist, 61, 315327.

Budak, F., \& Korkmaz, Ş. (2020). An overall evaluation for the COVID-19 pandemic process: The case of Turkey. Journal of Social Research and Management (SAYOD), (1), 62-79 (in Turkish).

Cumberland-Li A, Eisenberg N, \& Reiser M. (2004). Relations of young children's agreeableness and resiliency to effortful control and impulsivity. Social Development, 13, 193-212.

Calışkan, Y. (2020). COVID -19 pandemic and quarantine process on child mental health. Medical Research Reports, 3(Special Issue), 149-154 (in Turkish).

Çorapçı F., Aksan N., Arslan -Yalçın D. \& Yağmurlu B. (2010). Emotional, behavioral and social adjustment screening at school entry: social competence and behavior evaluation-30 scale. Turkish Journal of Child and Adolescent Mental Health, 17(2), 63-74 (in Turkish).

Eisenberg N., Spinrad T. L., Fabes R. A., Reiser M., Cumberland A., Shepard S. A., \& Thompson, M. (2004). The relations of effortful control and impulsivity to children's resiliency and adjustment. Child Development, 75 (1), 25-46.

Gizir C. A. (2007). A literature review of studies on resilience, risk, and protective factors. Turkish Psychological Counseling and Guidance Journal, 3, 113-126 (in Turkish).

Grotberg, E. H. (1995). A guide to promoting resilience in children: Strengthening the human spirit (No. 8). The Hague, Netherlands: Bernard van leer foundation.

Gülay Ogelman, H., \& Çiftçi Topaloğlu, Z. (2014). Monitoring the relationships between social competence, aggression, anxiety levels of 4-5 year old children and their mother and father's parental perceptions of self-efficacy. Bolu Abant izzet Baysal University Journal of Faculty of Education, 14 (1) 241-271 (in Turkish).

Gültekin Akduman, G., Günindi, Y. \& Türkoğlu, D. (2015). The investigation of the relations between social skills level and behavioral problems in preschool children. The Journal of International Social Research, 37, 673-683 (in Turkish).

Karaırmak, Ö. (2006). Resilience, risk and protective factors. Turkish Psychological Counseling and Guidance Journal, 3(26), 129-142 (in Turkish).

Masten AS, \& Coatsworth JD. (1998). The development of competence in favorable and unfavorable environments: lessons from research on successful children. American Psychologist. 53, 205-220.

Masten A. S., \& Gewirtz A. H. (2006). Resilience in development: The importance of early childhood. In: Tremblay RE, Barr RG, Peters RDeV, eds. Encyclopedia on Early Childhood Development [online]. Montreal, Quebec: Centre of Excellence for Early Childhood Development; 1-6.

MEB (2021a). 2020-2021 Eğitim Öğretim Yılının İkinci Dönemi Uzaktan ve Yüz Yüze Eğitimle Başlıyor. 03 January 2021 retrieved from https://www.meb.gov.tr/2020-2021-egitim-ogretim-yilinin-ikincidonemi-uzaktan-ve-yuz-yuze-egitimle-basliyor/haber/22553/tr (in Turkish).

MEB (2021b). Basın Açıklaması - Eğitimde Kontrollü Normalleşme Sürecinde Eğitim Kurumlarının Açıma Ve Uygulama Kriterleri. 03 January 2021 retrieved from https://www.meb.gov.tr/basin-aciklamasi- 
egitimde-kontrollu-normallesme-surecinde-egitim-kurumlarinin-acilma-ve-uygulamakriterleri/haber/22651/tr (in Turkish).

Mihaela, T. I. (2015). Promoting the emotional wellbeing of preschoolers. Procedia-Social and Behavioral Sciences, 209, 509-513.

Miljević-Riđički, R., Plantak, K., \& Bouillet, D. (2017). Resilience in preschool children: The perspectives of teachers, parents and children. International Journal of Emotional Education, 9(2), 31-43.

Önder, A., \& Gülay, H. (2008). Resilience of 8 Grade Students in Relation to Various Variables. Buca Faculty of Education Journal, (23), 192-197 (in Turkish).

Önder, A., \& Gülay-Ogelman, H. (2011). The reliability-validity study for the Ego Resiliency Scale (TeacherMother-Father Forms) for children aged between 5 and 6, International Refereed Academic Social Sciences Journal, 2(1), 5-21.

Özdamar, K. (2004). Statistical data analysis with package programs 2. Eskişehir: Kaan Publishing (in Turkish).

Reed-Victor, E., \& Stronge, J. H. (2002). Homeless students and resilience: Staff perspectives on individual and environmental factors, Journal of Children Poverty, 8(2), 159-183.

Swanson J., Valiente C., Lemery-Chalfant K., \& O'Brien T. C. (2011). Predicting early adolescents' academic achievement, social competence, and physical health from parenting, ego resilience, and engagement coping. The Journal of Early Adolescence, 31,548-576.

Sun, J., \& Stewart, D. (2007). Age and gender effects on resilience in children and adolescents. International Journal of Mental Health Promotion, 9(4), 16-25.

Taylor, Z. E., Eisenberg, N., VanSchyndel, S. K., Eggum-Wilkens, N. D., \& Spinrad, T. L. (2014). Children's negative emotions and ego-resiliency: Longitudinal relations with social competence. Emotion, 14(2), 397-406.

The Ministry of Education (2020). Face-to-Face Education in Pre-School Education. 01 December 2020 retrieved from http://ookgm.meb.gov.tr/meb iys dosyalar/2020 11/20133842 okul-oncesiegitim-kurumlarinda-yuz-yuze-egitim.pdf (in Turkish).

Turan, U. D. C. K., \& Hacımustafaoğlu, M. K. (2020). Coronavirus disease in children 2019 (COVID-19): Differences and approaches in children (pp. 81-106). In Heper, C. (Ed.), Multidisipliner COVID-19. Bursa, Bursa Chamber of Medicine publications. 01 December 2020 retrieved from https://www.ttb.org.tr/kollar/userfiles/files/bto covid 19 kitap.pdf\#page=82 (in Turkish)

Um, B. (2018). Ego-resiliency, parenting style, and peer attachment as predictors of South Korean middle school students' school adjustment. Redfame: International Journal of Social Science Studies, 6(7), 14-30.

Yağan Guder, S. (2014). Investigating preschool children's perception of gender. Doctoral dissertation. Ankara: Hacettepe University (in Turkish). 